\section{Sir Martin Roth}

Sir Martin Roth, Emeritus Professor of Psychiatry at the Untversity of Cambridge, has been elected a Fellow of the Royal Society.

\section{The Communication Award}

The Conference of Medical Royal Colleges Award for effective communication with patients, in association with BUPA is now inviting entries for the 1996 Award. Entries, which may cover any or all of the categories of the Medical Royal Colleges or their faculties, are now canvassed from Members and Fellows of the Colleges. They will be considered by a panel of lay and medical judges chaired by a medical journalist. The result will be announced, and the presentation made, at a ceremony at Lincoln's Inn on the 14 November 1996 (Award helpline: Ms Diana Garrett: 0171290 3913).

\section{New publications}

The Mental Health Digest is an entirely independent publication, written for people with an informed interest in mental health. It offers summaries of articles selected from leading professional journals and is avallable for an annual subscription of $\$ 6$. Further information: Barbara Kuper, Mental Health Digest Ltd, 77 Maldon Road, Brighton BN1 5BD (telephone: 01273564 208).

Helping Children Cope with Stammering by Trudy Stewart and Jacke Turnbull is now avallable from Sheldon Press. Price: 86.99. Further information and Bookshop. Holy Trinity Church, Marylebone Road, London NW1 4DU (telephone: Laura Musgrove 0171387 5282).

Talking About Anorexia by Maroushka Monro is also available from Sheldon Press (details as above) and is priced at $\$ 5.99$.

The new publication Publicity for Mental Health Cltnicians by Doug Ruben is now avallable from the Haworth Press, 10 Alice Street, Binghampton. NY 13904-1580, USA (telephone: (607) 7225857 ext. 326; fax (607) 722 6362).

A new leaflet entitled Schizophrenia has been produced by the Royal College of Psychiatrists in assoclation with the National Schizophrenia Fellowship. For single copies please send an SAE to the Royal College of Psychiatrists, 17 Belgrave Square, London SWIX 8PG. For bulk orders contact Mary Ayres, also at the College, on 01712352351 ext. 259. 